\title{
Challenges of Maturity Models in Public-Private Partnerships (PPPs) in the Post-COVID-19 Era
}

\author{
Yusuf Umar Datti ${ }^{1}$, Noor Amila Wan Abdullah Zawawi ${ }^{2}$, Abdullahi Ahmed Umar ${ }^{3}$, Muslich Hartadi Sutanto ${ }^{4}$, and \\ Kamaluddeen Usman Danyaro ${ }^{5}$ \\ ${ }^{1}$ Ph.D. Student, Department of Civil Engineering, Faculty of Engineering, Universiti Teknologi PETRONAS, 32610 Seri \\ Iskandar, Perak, Malaysia. \\ ${ }^{2}$ Associate Professor, Department of Civil Engineering, Faculty of Engineering, Universiti Teknologi PETRONAS, \\ 32610 Seri Iskandar, Perak, Malaysia. Email: amilawa@utp.edu.my (corresponding author). \\ ${ }^{3}$ Department of Civil Engineering and Quantity Surveying, Military Technological College, Muscat, Oman \\ ${ }^{4}$ Senior Lecturer, Department of Civil Engineering, Faculty of Engineering, Universiti Teknologi PETRONAS, 32610 \\ Seri Iskandar, Perak, Malaysia \\ ${ }^{5}$ Lecturer, Department of Computer and Information Sciences, Faculty of Science and Information Technology, \\ Universiti Teknologi PETRONAS, 32610 Seri Iskandar, Perak, Malaysia
}

\begin{abstract}
Maturity models (MMs) have witnessed exponential increase due to their successful application in several domains. However, there is an absence of review that guides researchers in developing, applying and validating PublicPrivate Partnership maturity models (PPPMMs). This study examines PPPMMs, provides guidance on the topic and highlights gaps in the literature. A literature search on selected electronic databases was conducted, and the study adopted the widely accepted Preferred Reporting Items for Systematic Review and Meta-analysis statement (PRISMA). The study identified a total of four thousand six hundred and eighteen $(4,618)$ studies, and twenty-one studies $(21 \mathrm{Nr})$ were rigorously selected. The results revealed PPPMMs as an emerging area of research with a low number -21 publications since its deployment for about two (2) decades. Similarly, the findings unveiled a lack of uniformity in conceptualising the terms, dimensions used, and methodology adopted. This finding is attributed mainly to the limited use of the theoretical lens, which considerably weakens the model's theoretical foundation and limits its potential to guide improvement. Additionally, there are more efforts in developing MMs than applying and validating them. Furthermore, there is an unbalanced focus on descriptive models over prescriptive and comparative models, which inhibit the model's potential to guide improvement. Future work should provide a solid ground to the field using a theoretical lens and focus on prescriptive models with a strong emphasis on application and validation. This research is the first of its kind that synthesises and brings together available PPPMMs literature into one place. It also contributes to the body of knowledge by highlighting areas of research that require immediate attention to enhance the much-needed success of PPP in the post-COVID-19 era.
\end{abstract}

Keywords: Maturity models, public-private partnership, descriptive model, prescriptive model, COVID-19.

Copyright $\odot$ Journal of Engineering, Project, and Production Management (EPPM-Journal).

DOI 10.32738/JEPPM-2022-0014

\section{Introduction}

Globally, public-private partnerships (PPPs) have proven to be a potent infrastructure financing and delivery tool and hence its growing popularity. Despite this increasing popularity and expected benefits of adopting PPPs, several researchers have reported mixed adoption and outcome of PPPs (Miyamoto and Biousse, 2014; Romero, 2015; World Bank, 2020a) across different regulatory, institutional and political contexts (Casady et al., 2018; Deloitte, 2007; The Economist Intelligence Unit (EIU), 2015; United Nations Economic Commission for Europe (UNECE), 2013; Verhoest et al., 2014; Verhoest et al., 2015; World Bank, 2021a; Yescombe, 2017). Furthermore, a growing body of literature has reported wide disparity in the infrastructural gap between emerging and advanced economies, with a severe deficit in lower and middle-income countries (LMIC) where basic infrastructures fall short of what is needed for a decent and sustainable life, let alone economic prosperity. For instance, one-quarter of the world population lack access to improved sanitation facilities, one-eight are without electricity and have restricted access from an all-season road, more than one-tenth lack improved sources of drinking water, and uncounted numbers are unable to access work and educational opportunities (Rozenberg and Fay, 2019). 
Consequently, the emergence of the COVID-19 pandemic has further exacerbated the problem of infrastructure provision in both upper-middle-income countries (UMICs) and LMICs (World Bank, 2021b). Additionally, an analysis of 7,249 PPP projects (excludes privatisation) in 137 LMIC between 1990-2020 in the Private Participation in Infrastructure Database revealed a limited number of projects in Sub-Saharan Africa 479 (6.61\%) and the Middle East and North Africa 207 (2.86\%) as compared to other regions of the world (Romero, 2015; World Bank, 2021a). Similarly, the number of PPP projects in industrialised countries such as the United Kingdom (800) is more than the combined projects in SubSaharan Africa, and the Middle East and North Africa (788) (World Bank, 2021a). The emergence of "Peoplefirst PPP" has sought to overcome these deficits by providing critical infrastructures for a decent and sustainable life (UNECE, 2018). Still, the current wave of remunicipalisation that is spreading worldwide has made many researchers question the effectiveness of PPP in the public provision of infrastructures (Hall and Hobbs, 2017; Kishimoto and Petitjean, 2017; Whitfield, 2017).

Umar et al. (2019) have linked the current wave of remunicipalisations to be related to the increasing failures of PPP projects. Similarly, Whitfield (2017) reported that remunicipalisations were associated with poor PPP performance, construction failure, cost overruns and delays, excessive operational charges, legal challenges, and prevention of public policy implementation. To address these failures, researchers have developed maturity models to help organisations and countries in this regard. Babatunde et al. (2016) highlighted the relevance of maturity assessment on PPP development, implementation, and performance. Despite this recognition, limited studies are investigating the maturity of PPP in emerging economies.

Similarly, a growing number of academic literature has indicated the significance of maturity assessment in managing organisations' results and public provision of infrastructure and services (Bititci et al., 2015; Deloitte, 2007; Humphrey, 1997). Bititci et al. (2015) investigated the practical value and usefulness of maturity models in performance measurement (PM). They revealed that the use of maturity models (MMs) promotes more significant levels of organisational learning. Moreover, Babatunde et al. (2016) asserted MM to enhance the success rate of PPP project implementation by providing a valuable guide for assessing a country's strengths and weaknesses. This technique provides organisations or governments with a measuring tool for auditing and benchmarking (Proença and Borbinha, 2016; Ruikar et al., 2006) and further identifies the critical issues for achieving maturity/readiness by companies (Ruikar et al., 2006). Additionally, maturity assessment can minimise the probability of high-impact failures at the project, program, or portfolio levels (Project Management Institute (PMI), 2013) and provides a roadmap for continual progression and improvement (Humphrey, 1997; OGC, 2010).

Despite these potential benefits that MMs could bring to the field of PPP, especially in the post-COVID-19 era, there is a lack of studies that appraise and bring together existing MMs studies into one single place. In contrast, several researchers have conducted systematic reviews in other domains, such as software engineering (GarcíaMireles et al., 2012; Khoshgoftar and Osman, 2009), business process management (de Bruin et al., 2005; Tarhan et al., 2016), project management (Khoshgoftar and Osman, 2009), knowledge management (de Bruin et al., 2005), education and research domain (García-Mireles et al., 2012), information technology (Becker et al., 2009; Pereira and Serrano, 2020; Solli-Sæther and Gottschalk, 2010), healthcare (García-Mireles et al., 2012; Maier et al., 2012), management science, new product development, and engineering design (Maier et al., 2012), supply chain and sustainability (Correia et al., 2017). However, little attention was paid to such reviews within the domain of PPP. This lack of reviews for authors of PPP Maturity models has led to new works being developed without a suitable theoretical base and new terms being developed for concepts already described elsewhere (Maier et al., 2012). Additionally, Khoshgoftar and Osman (2009) highlighted the importance of considering the specific characteristic of different domains/organisations in developing generic models. This paper fills the void by reviewing existing maturity models, providing new guidance on the topic, suggesting a more rigorous approach to its development, and highlighting gaps in the literature.

The study conducted a systematic literature search on selected electronic databases and adopted the widely accepted Preferred Reporting Items for Systematic Review and Meta-analysis statement (PRISMA). The rest of the paper is structured as follows: Section 2 describes the methodology used in conducting the research. Section 3 analyses and discuss the findings. While Section 4 summarises the findings of the study.

\section{Research Methodology}

The exponential growth of published research brings difficulty in searching relevant literature and, hence the need for an effective search strategy (Atkinson and Cipriani, 2018). Thus systematic review addresses this problem by appraising, summarising, and bringing together all work (published and unpublished) into one place using a well-defined and organised process to answer a specific question (Nightingale, 2009; Tawfik et al., 2019). Therefore this research adopted this methodology to give direction on the topic and provide insight into future research paths in PPP. Nightingale (2009) revealed that this methodology minimises the effect of selection and data extraction bias. The main contribution of this paper is to summarise existing literature about the development, application, and validation of PPP MMs, provide guidance on the topic, highlight gaps in the literature and put together plausible options for successful PPP Implementation. A preliminary review has led to the emergence of the following hypothesis:

1) There is no clear terminology of what maturity encapsulates in PPP maturity literature.

2) There have been more efforts in developing generic PPP maturity models than specific models that would address specific problems. 
3) There have been more efforts to develop PPP maturity models than empirically evaluate them (application and validation).

4) PPP maturity models are mainly descriptive than prescriptive or comparative.

5) There has been an unbalanced adoption of the mono research method in developing, evaluating, and assessing the maturity model rather than the mixed research method.

The study was conducted through a six-part methodology as follows:

\subsection{The First Step Involves Locating and Selecting the Right Literature Source to Search}

Any systematic review's success depends on identifying and retrieving relevant literature sources (Smith et al., 2011). Smith et al. (2011) suggest searches in a systematic review of the literature to be comprehensive. The purpose is to maximise the possibility of capturing all relevant data while minimising the effects of reporting biases. In this regard, the study would include multiple databases such as SCOPUS, ScienceDirect, Emerald Insight, EBSCOhost, Google Scholar, and Web of Science. Google Scholar was added to the list because it provides a robust open-access database that archives "grey literature," such as conference proceedings, thesis, and reports, in addition to the journal articles (Xiao and Watson, 2019). The aim is to ensure that the review is comprehensive, thorough, and inclusive. To further lessen the chances of letting out any relevant paper in the study, forward and backward searching were adopted in addition to the electronic database searching.

\subsection{The Second Step Involves Identifying Keywords and Developing the Search String}

The study conducted an initial literature review to identify the searches terms for the literature search. The search terms were selected based on their relevance to the research hypothesis. Thus, using the above criteria, the following relevant keywords were identified; "PPP maturity models," "PPP Maturity," "PFI Maturity," "PPP readiness," "PPP readiness assessment," "PPP maturity framework," "PPP Governmental Support index (PPPGSI)," "PPP readiness Framework." Therefore this research establishes the following search string:

TITLE-ABS-KEY ((“Public-private partnership" OR PPP OR "Private finance initiative" OR PFI) AND (maturity OR "Maturity Models" OR "maturity Framework" OR Readiness OR "Readiness assessment" OR "readiness framework" OR Capability OR "capability model" OR "Capability framework" OR "Governmental Support index" OR GSI)). As for GOOGLE SCHOLAR, the above search strings were revised, which gave rise to the second search string, as follows; (("Public-private partnership" OR "PPP" OR "Private Finance Initiative" OR "PFI") AND ("Maturity Models" OR "maturity Framework" OR "Readiness assessment" OR "readiness framework")).

2.2. The Third Step Involves Establishing the Screening Criteria System and Conducting the Search
Establishing the inclusion and exclusion criteria involves setting criteria that would ensure the selection of relevant papers. The following are the inclusion criteria for the selection of relevant literature journal articles, proceedings of conferences, books, governmental and nongovernmental reports, working papers written in English, whose content includes any of development, application, evaluation, or validation of PPP maturity/readiness models, but does not consider date filter. The purpose is to obtain the widest available literature on PPP maturity models as possible. Previous studies on maturity models are limited to journal or conference papers. For example, Tarhan et al. (2016) and García-Mireles et al. (2012) limited their review to journal articles and conference proceedings. In addition to journal articles and conference papers, Pereira and Serrano (2020) included scientific magazines in their analysis. Thus, there is a need to widen the consideration of the literature to obtain comprehensive studies of PPP maturity models that would be representative of existing literature. The inclusions of practitioners' literature, such as non-governmental and international consulting bodies, could counterbalance the academic literature. Consequently, these criteria lead to a balanced and unbiased literature summary.

The exclusion criteria for this search include all papers that present maturity/readiness models outside PPP. Additionally, the keyword search was limited to the article title, abstract, or author keywords. The purpose was to select papers relevant to the research question. Moreover, the study excludes duplicate data from the sample. Equally excluded from this review are articles for which full texts were not accessible. The authors conduct searches on each electronic database, and Fig. 1, the widely accepted Preferred Reporting Items for Systematic Review and Meta-analysis statement (PRISMA), presents the screening and selection procedure details. This procedure was in line with the recommendation of Moher et al. (2009). After the initial screening of the duplicates, the search reveals four thousand six hundred and nine $(4,609)$ studies.

\subsection{The Fourth Step Involves Screening for Inclusion}

This step involves skimming through the abstract and title of the retrieved articles for relevance and duplication. The study includes any potential research that appears to answer the research question or offers guidance; otherwise, the authors exclude it from the analysis. Similarly, the authors manually removed duplications in this stage. When there is doubt about the article's relevance, the decision shall be to include rather than to exclude it. A total of thirty-one (31) studies were deemed relevant, and the fulltext articles were obtained for quality assessment.

\subsection{The Fifth Step Involves Reviewing the Content of the Searched Articles for Quality and Eligibility Assessment}

The authors reviewed the full-text copies of the potentially eligible papers to evaluate their quality and eligibility for this study. A careful review excluded a total of eleven (11) studies due to lack of guidance on literature; similarly, the study could not find the full text of one (1) article. A total of twenty-one studies $(21 \mathrm{Nr})$ from the initial search make it to the next stage of full-text analysis. 


\subsection{The Sixth Step Involves Data Extraction and Analysis}

After undergoing all the above screening and quality appraisal, twenty-one studies $(21 \mathrm{Nr})$ overall were reviewed. This stage involves reading the papers in full, followed by summarising and extracting relevant information for documentation and presentation purposes. Thereafter, the data were systematically extracted from each article and tabulated in appendix 1 to answer the research hypothesis.

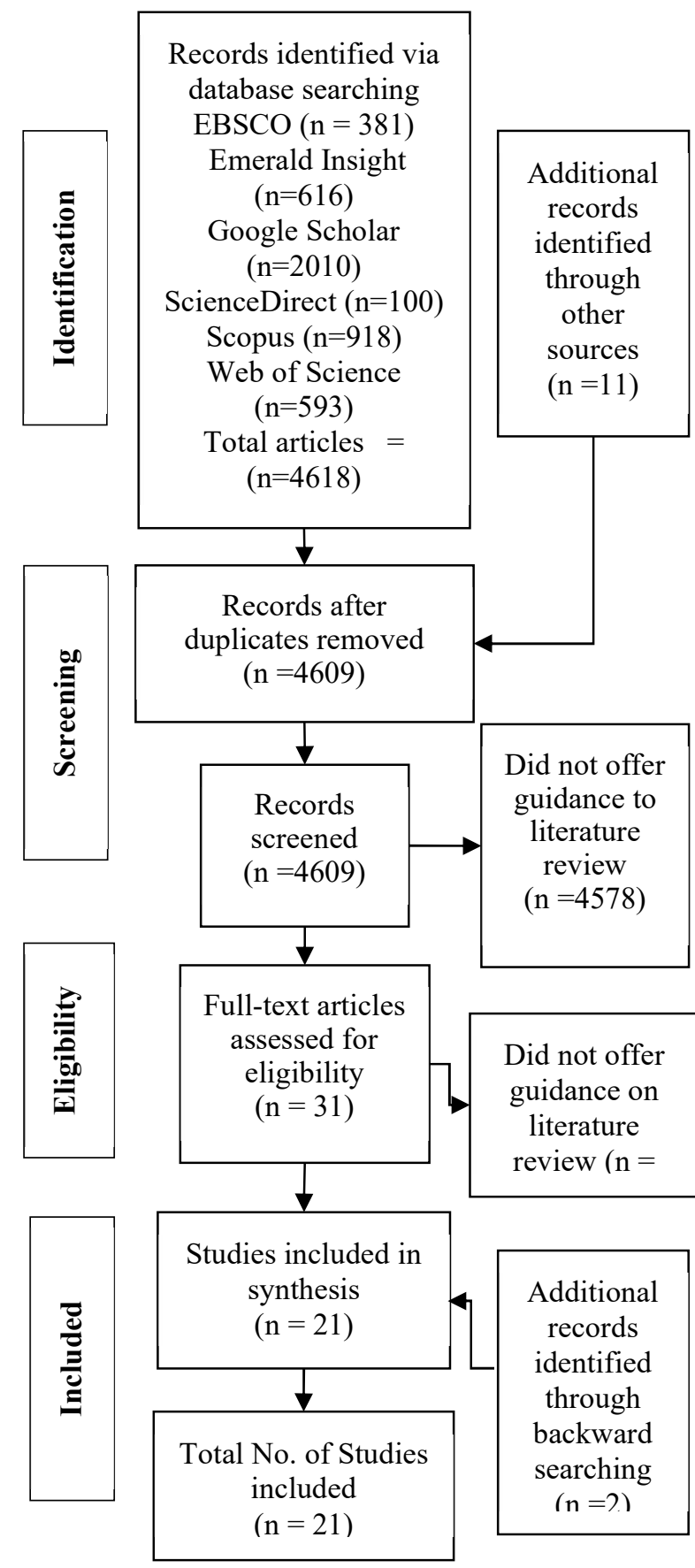

Fig. 1. PRISMA flow diagram of studies' screening and selection

\section{Results and Discussions}

Presented below are the results of the data extracted from the literature. Fig. 2 below shows the distribution of the articles by type of publication. In terms of publication type, journal articles publication holds the largest share with eight (8) publications, followed by reports and conference proceedings with 6 and 4 publications, respectively, while theses have the least share with one (1) publication. Thus, a good representation can be seen across publications, minimising publication bias.

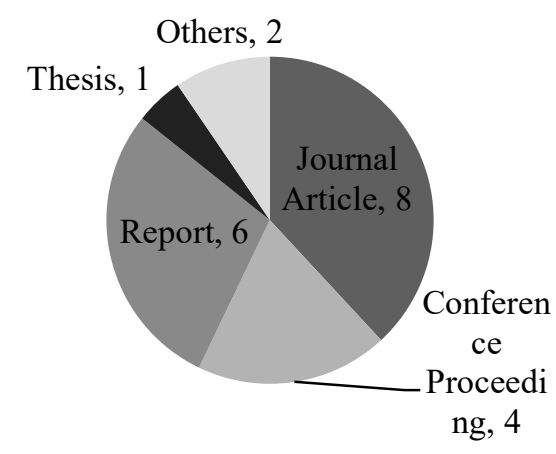

Fig. 2. Articles by type of publication

\subsection{Year of Publication and Continent of Origin of the Model}

Fig. 3 shows the distribution of articles by year of publication. The figure reveals a low number of maturity model publications in the domain of PPP (21 publications), and that only emerged in 2007. There is a steady rise in publications from one publication per year to its historical peak of 4 publications per year in 2016 and 2020. The study attributes this trend to the advent of "People first PPP," a new variant of PPP where people's priority is placed at the core of public provision of infrastructures (UNECE, 2018). Similarly, the growing rollouts of COVID-19 vaccination, together with the increasing hope of returning to normalcy, have further stimulated interest in PPP in the second half of 2020 (World Bank, 2021b). However, there was a noticeable decline in 2017 and a steady rise till 2020. The apparent decline in 2017 may not be unconnected with the general discrediting of the model by the UK government with a decision to abandon the model (HM Treasury, 2018) and the wave of remunicipalisation of public infrastructures that are taking place in Europe, Oceania, and America during the last 15years (Becker, 2017; Hall and Hobbs, 2017; Kishimoto and Petitjean, 2017; Lobina et al., 2014). Additionally, the slow pace of PPP between 2008-2013 was attributed to the global financial crises witnessed between 2007-2009 coupled with European debt crises between 2009-2013, which further slowed PPP development.

Furthermore, the African continent takes the lead with the highest publications of six (6), followed by Asia with five (5). Europe has the second-lowest number of publications with two (2) publications only, while Russia, South America, and Australia have no publications. The result indicated a surprising trend with continents with low-and middle-income - Africa and Asia outstripping upper-income continents such as Europe, Oceania, and America in PPP maturity research. This trend may not be unconnected with the increasing wave of remunucipalisation of public services in Europe, Oceania, and America during the last 15years (Becker, 2017; Hall and Hobbs, 2017; Kishimoto and Petitjean, 2017; Lobina et al., 2014). For example, the number of 
remunicipalisation cases in high-income countries has doubled over the last five years from 41 in 2009 to 81 in 2014 (Lobina et al., 2014), resulting in lesser interest in PPP and PPP maturity research in these continents. While PPP in Africa and Asia experienced significant growth within the same period, for example, from 2004-2012, investments in PPPs increased by a factor of six, from US22.7 billion to US134.2 billion dollars in developing countries (Romero, 2015) hence instigating the need for more maturity assessment as compared to developed continents.

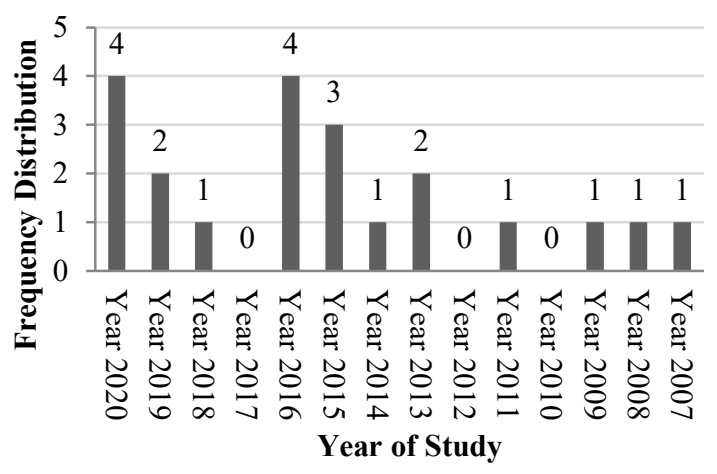

Fig. 3. Distribution of articles by year of publication

\subsection{Terminologies and Dimensions Used in PPP Maturity Literature}

The first research hypothesis seeks to verify whether there is a clear terminology of what maturity encapsulates in PPP maturity literature. In verifying this argument, we reviewed the publications in the sample to identify the terminologies used in PPP maturity research and the dimensions used in evaluating PPP maturity. Fig. 5 reveals the various terminologies used in PPP maturity literature and it ranges from "PPP readiness," "PPP Maturity," "PPP Institutionalization," "PPP Governmental support index (GSI)," "The Concordia Partnership Index," "PPP environment evaluation" and "Benchmarking Infrastructure Development Index."

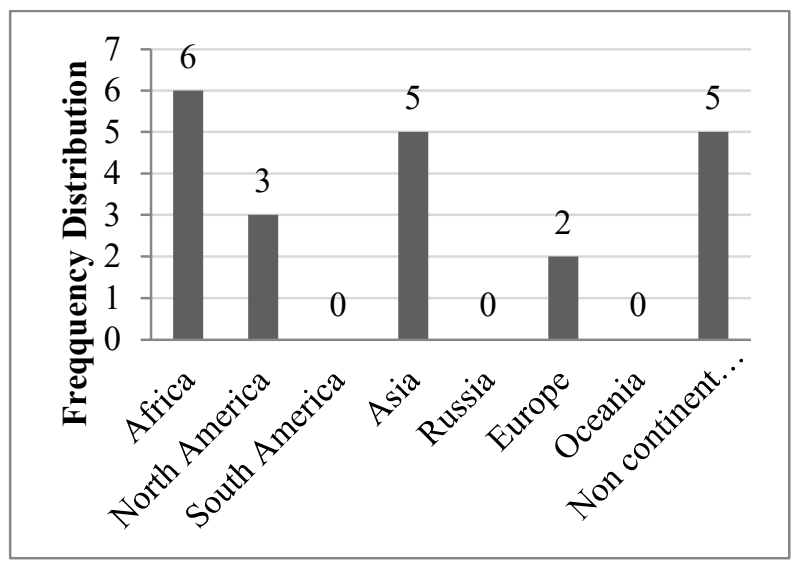

Fig. 4. Model distribution by continent

Moreover, from Fig. 5, "PPP readiness" predominates all labels in PPP maturity research, with 11 out of 21 studies (Al-shareem et al., 2013, 2015; Chileshe and Kavishe, 2020; Kavishe and Chileshe, 2019; Malik and Kaur, 2020; Putri and Wirahadikusumah, 2019; Soomro et al., 2016; UNECE, 2011, 2013; United Nations Economic and Social Commission for Asia and the Pacific
(UNESCAP), 2014; World Bank, 2016) adopted it. The second most used terminology is "PPP Maturity," with 5 out of 21 studies (Babatunde et al., 2016; Casady et al., 2020; Deloitte, 2007; Phungula, 2008; Rwelamila and Phungula, 2009) adopted it. While "PPP Institutionalization" (Casady et al., 2018), "PPP GSI" (Verhoest et al., 2015), "The Concordia Partnership Index" (Concordia, 2016), "PPP environment evaluation" (EIU, 2015) and Benchmarking Infrastructure Development (World Bank, 2020b) have one publication each adopting it. This result revealed a wider divergence in terminologies used, with terms such as "PPP readiness," "PPP Maturity," "PPP Institutionalization," "PPP GSI," "PPP environment evaluation," and Benchmarking Infrastructure Development interchangeably refers to mean the same thing.

Furthermore, appendix 1 has identified the dimensions used to evaluate PPP maturity worldwide. The dimensions can be seen in varying degrees of detail, as presented in appendix 1. While majority lump together different contextual elements, which makes the assessment too broad, unfocused, and difficult for interpretation. Also, it is relatively less helpful in guiding organisational learning and continuous improvement. Few studies used theoretical perspective, as highlighted in Table 1, to give direction and to limit the scope of the model (Al-shareem et al., 2015, 2013; Casady et al., 2018, 2020; Chileshe and Kavishe, 2020; Kavishe and Chileshe, 2019; Verhoest et al., 2015). An appreciable number of papers, 14 out of 21 (Babatunde et al., 2016; Concordia, 2016; Deloitte, 2007; Malik and Kaur, 2020; Phungula, 2008; Putri and Wirahadikusumah, 2019; Rwelamila and Phungula, 2009; Soomro et al., 2016; EIU, 2015; UNECE, 2011，2013; UNESCAP, 2014; World Bank, 2016, 2020) did not explicitly use any theoretical framework. Thus, this finding confirms the hypothesis that there is no clear terminology of what maturity encapsulates in PPP maturity research. Furthermore, the wider divergence of terms and dimensions used and the limited use of theoretical lens indicates that maturity research within the domain of PPP is at an early conceptual stage. The findings also indicate that most studies are developing models without reviewing existing models in the PPP domain. This result corroborates with Maier et al. (2012), who revealed that researchers introduced new terminologies for concepts already described elsewhere. This trend is attributed to the limited use of the theoretical lens, which considerably weakens the theoretical foundation of the models and limits their potential to guide improvement. Therefore, there is a need for uniformity and standardisation in terms/labels and dimensions used in PPP maturity research.

\subsection{Scope of PPP Maturity Models}

The second research hypothesis seeks to verify whether more efforts exist in developing generic PPP maturity models than specific models that would address specific problems. Table 1 revealed two distinct scopes of maturity models: Generic maturity and Specific maturity models. Specific PPP maturity models dominated the existing research with 14 out of the 21 publications, and its scope ranges from "sectors," "critical success factors," and "people." In the review, the specific maturity models with 
a scope on "sectors" have transport with two (2) studies (Putri and Wirahadikusumah, 2019; Soomro et al., 2016) and social services infrastructure (housing to be specific) with three (3) studies (Al-shareem et al., 2013; Chileshe and Kavishe, 2020; Kavishe and Chileshe, 2019). Additionally, the scope on "critical success factors" range from studies on institutional factors with four (4) studies (Casady et al., 2018, 2020; Verhoest et al., 2015; World Bank, 2020b) to project management with two (2) studies (Phungula, 2008; Rwelamila and Phungula, 2009). The last category is the maturity model with a scope on "people." This category has two (2) studies related to PPP stakeholders and practitioners (Al-shareem et al., 2015; Babatunde et al., 2016). While only 8 out of 21 publications exist (Concordia, 2016; Deloitte, 2007; EIU, 2015; UNECE, 2013, 2011; UNESCAP, 2014; World Bank Group, 2020, 2016) on generic PPP maturity models. This finding nullifies the hypothesis that researchers are spending more effort developing generic PPP maturity models than PPP-specific models that would address specific problems. This trend may be due to the failure of the generic model to address the problem arising from its lumping of different contextual elements, which would make identification of the problem and interpretation of the result difficult. It may also be because specific models are more likely to discern the problem in question than their generic counterparts.

\subsection{The objective of PPP MM Studies}

The third research hypothesis seeks to verify whether more efforts exist in model development than its application and validation. In verifying this argument, we investigated the objectives of the existing maturity models and their research focus. Fig. 6 shows significant differences in the number of maturity models that focus on model development compared to model validation. The result revealed that $71 \%$ of the models focused on the developments and $29 \%$ on the application of the models, while no publication exists with the sole objective of model validation alone. Thus, this confirms that studies spend more effort developing maturity models than empirically applying and validating them. This finding is similar to that of Tarhan et al. (2016) in the field of Business Process Management (BPM) and Correia et al. (2017) in the domain of Information Technology (IT). The result also reveals that no maturity models exist with the sole objective of validation in the PPP domain. This result is in stark contrast to the findings of the IT domain, where application rather than validation is scarce (Correia et al., 2017). For instance, out of the 15 articles whose sole objectives are developments, 11 were deployed for applications in addition to their sole objective (11 out of 15 articles). While few studies, four (4) articles out of 15 models were validated and applied. Furthermore, one study by (Deloitte (2007) in which the developed model is neither validated nor applied. Thus, from the above discussions, there is the need for future studies to operationalise PPP MMs by applying and validating them, as against model creation only, since validation determines the degree of accuracy of the model in representing reality (Sornette et al., 2007) and confirms whether the correct model was build or not (Hahn, 2013). The lack of validation provides limited evidence by existing studies regarding the use and usefulness of these models in practice.

\subsection{Purpose of the PPP MM (Assessment or Guidance View)}

The fourth research hypothesis relates to the unbalanced focus on descriptive over prescriptive or comparative PPP models. In verifying this argument, we investigated the research focus of the existing maturity models. Fig. 7 shows the distribution of the publications by model type. All of the models except two Babatunde et al. (2016) and Verhoest et al. (2015) evaluate PPP maturity at one point in time (descriptive); they cannot monitor and guide improvement over time (prescriptive) nor have provision to enable benchmarking (comparative). This finding is similar to that obtained in BPM (Tarhan et al., 2016). Filho and Waterson (2018) defined a descriptive model as the model that describes essential or critical attributes that characterised an organisation at a particular level to understand the existing situations in the organisation. Tarhan et al. (2016) defined a prescriptive model as the model that describes defined practices through a maturation path and guides how to move from a lower maturity state to a higher one.

Using the above definitions, 19 out of 21 of the models exhibit descriptive properties (use in assessing " $a s$-is" situation without offering a roadmap for improvement to higher levels while only two models, Babatunde et al. (2016) and Verhoest et al. (2015) exhibited prescriptive properties (offer guidance on how to improve the capabilities of PPP critical success factors). It is noteworthy to mention that the model by Babatunde et al. (2016) is limited in scope to PPP stakeholders and 14 critical success factors, lacks theoretical underpinning and does not follow the rigorous scientific approach in selecting dimensions/key indicators. In contrast, Verhoest et al. (2015)'s model is limited to formal institutional elements and does not consider the informal institutional elements. Thus, from the above findings, we can see the dominance of the assessment view (Models based on descriptive features) in PPPMMs over the guidance view (models based on prescriptive properties). This trend severely limits the potential of the model to guide improvement. Thus, there is a need for more research on PPP MM that would focus on prescriptive models.

\subsection{Methods of Model Development, Evaluation, and Assessment}

The fifth research hypothesis relates to the unbalanced adoption of the mono research method in the development, evaluation, and assessment of the maturity model rather than the mixed method. In verifying this argument, we investigated the research methodology of the existing maturity models. Fig. 8 shows the distribution of the publications by their methods of development, evaluation, and assessment. The result revealed that literature review is the most dominant method of MM development, 8 out of 21 papers, followed by mixed research method, 4 out of 21 papers, while theory-building case-based analysis was the least method for developing the model, 2 out of 21 papers. It is noteworthy to mention that the mixed research method involves using more than one approach to develop a model. Putri and Wirahadikusumah (2019) used 
literature review and preliminary analysis, EIU (2015) used literature and workshop, and UNECE (2013) used literature review, pre-visit questionnaire, and consultation with experts in the development of their maturity model.

In evaluation, consultation with experts dominates the models' evaluation procedure ( 3 out of 21 ), followed by documentation review and mixed methods with one paper (1) each. About four-fifths of the publications were rarely evaluated (16 out of 21). This result confirms the findings of Figure 4 that PPPMMs are scarcely validated, and this signifies that existing studies attach less importance to the accuracy of the model's outcome than the model development and its usage.

The mixed research methods (a combination of more than two (2) methods) dominate the assessment procedure (7 out of 21), closely followed by the questionnaire methods (6 out of 21), while consultation with experts was the least method (1 out of 21). Three publications used a comparison to assess the maturity models; e.g., Rwelamila and Phungula (2009) used OPM3 and PMMM to assess the project management maturity of South African public institutions. Casady et al. (2018) used two maturity models in assessing the maturity of US PPP markets. Similarly, it is worthy to note that the mixed method is the only method that enjoyed widespread usage across the development, evaluation, and assessment with 4, 1, and 7 papers, respectively. Consultation with experts seems to be an emerging method of choice with usage across evaluation and assessment (2 stages) with 3 and 1 papers, respectively.

Thus, the results relatively confirm the hypothesis that the mono research method dominates the model development (literature review) and evaluation (consultation with experts), while the mixed research method dominates the assessment of PPP maturity models. However, the mixed research method is the only method that enjoyed wide usage across the three stages. Rwelamila and Phungula (2009) used a combination of literature review, case study, questionnaire, and open-ended structured interview, UNECE (2013) used consultation and pre-visit questionnaire, while EIU (2015) used interview, questionnaire and document analysis, e.t.c., as mixed

PPP environment evaluation

The Concordia Partnership Index

Benchmarking Infrastructure Development Index

$$
\begin{array}{r}
\text { PPP GSI } \\
\text { PPP insitutionalization } \\
\text { PPP Maturity } \\
\text { PPP readiness }
\end{array}
$$

methods of their choice in the assessment of models. Hence, the study observes a trend in the PPP model development, evaluation, and assessment. Also, the trends revealed the dominance of literature review in the development process, consultation with experts in the evaluation process, and mixed research methods in the assessment process.

\section{Conclusions}

The paper conducted a systematic literature review of MM in the domain of PPP. The purpose is to give insights into the development, evaluation, and validation of MMs in PPPs. The study utilised the widely accepted Preferred Reporting Items for Systematic Review and Meta-analysis statement (PRISMA). A total of four thousand six hundred and eighteen $(4,618)$ studies and twenty-one studies $(21 \mathrm{Nr})$ were rigorously selected. The results revealed that PPPMM is an emerging study area with a few (21 publications) documented since 2007.

Furthermore, the presence of diverse terminologies with wide variations in their meaning demonstrates a lack of sufficient understanding of the concept. Moreover, the findings revealed the absence of uniformity in the conceptualisation of the terms, dimensions used, and methodology adopted, which considerably weakens the theoretical foundation of the models and limits the potential of the model to guide improvement. Additionally, the result indicates a higher focus on model development over model application and validation. Concurrently, the finding revealed an unbalanced focus on descriptive models over prescriptive and comparative models, which severely limited the model's potential to guide improvement. Finally, the study partially confirms the hypothesis that the mono research method dominates the model development (literature review) and evaluation (consultation with experts). In contrast, the mixed research method dominates the assessment of PPP maturity models, which affects the reliability, accuracy, and value of the models in practice. Therefore, this paper contributed to the literature by synthesising and combining existing PPPMMs studies, highlighting their developments, applications, and validations challenges. Thus the need for future studies to address these downsides if there are to impact practice.

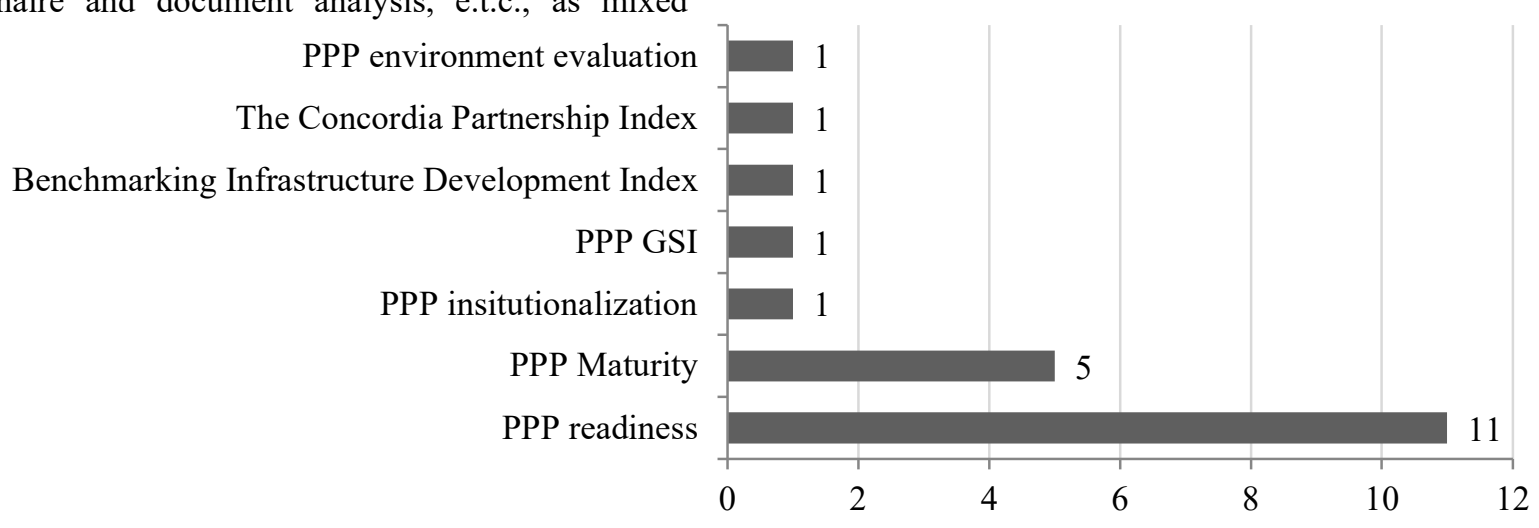

Fig. 5. Terminologies used in PPP maturity research

Table 1. Scope of PPP MMs and their theoretical lens

\begin{tabular}{ccccccc}
\hline \multirow{2}{*}{ Descriptions } & $\begin{array}{c}\text { Institutional } \\
\text { Theory }\end{array}$ & $\begin{array}{c}\text { Readiness } \\
\text { Theory }\end{array}$ & $\begin{array}{c}\text { Innovatio } \\
\text { n and }\end{array}$ & $\begin{array}{c}\text { Johnson et al.'s (2006) } \\
\text { \& Mrak's (2014) model } \\
\text { of institutionalisation }\end{array}$ & $\begin{array}{c}\text { No } \\
\text { theoretical } \\
\text { Lens }\end{array}$ & Total \\
\hline
\end{tabular}




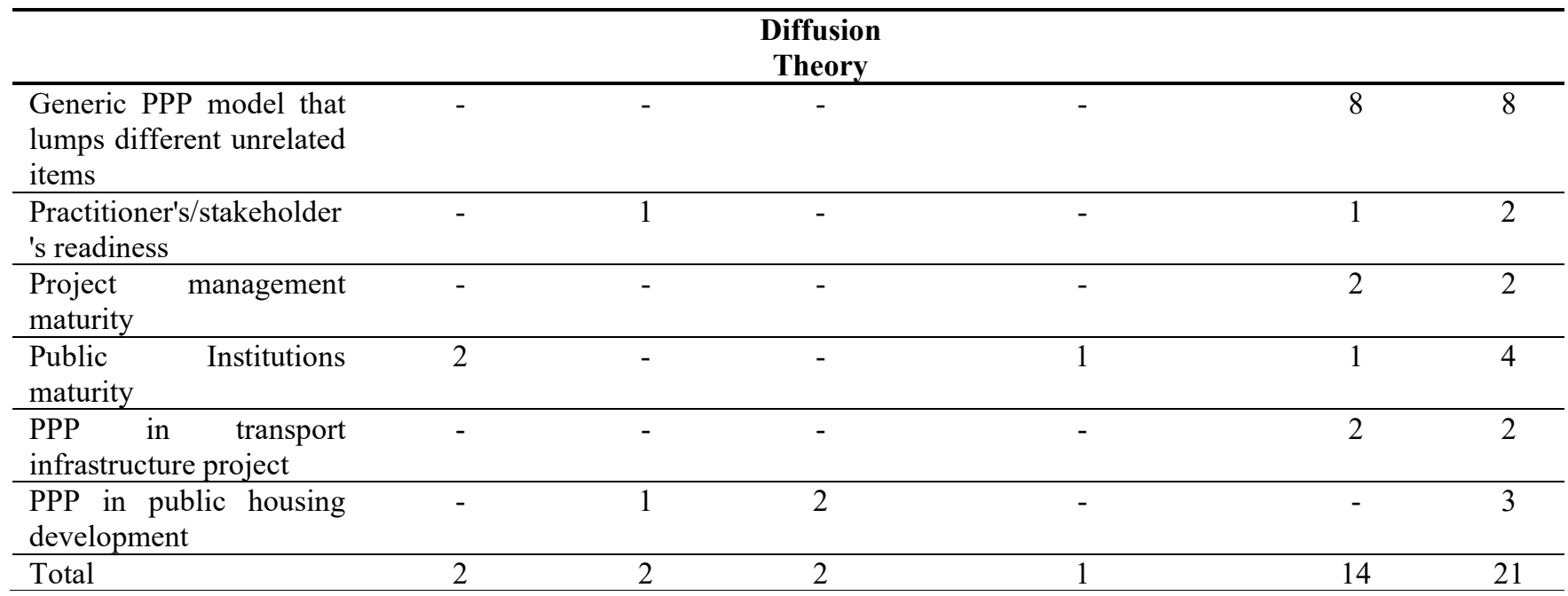

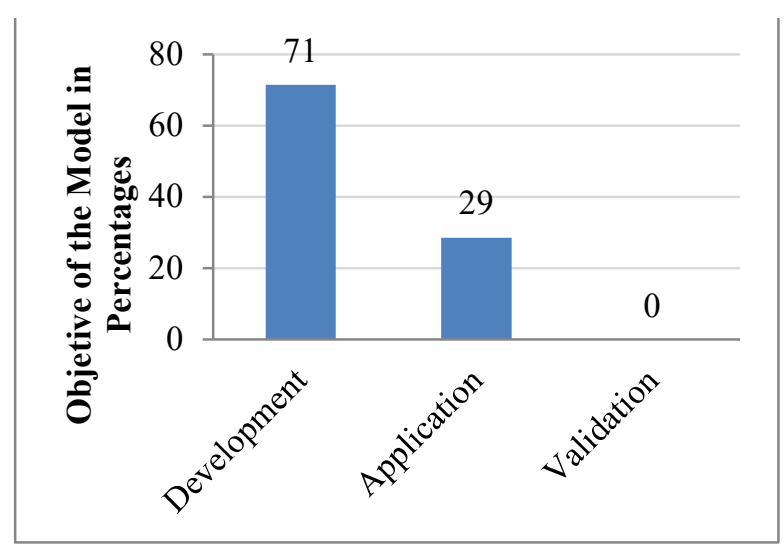

Fig. 6. Objective of the research

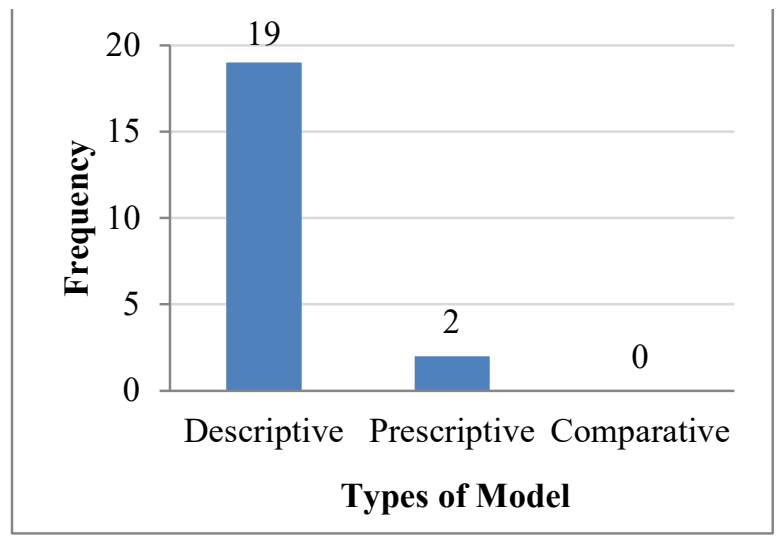

Fig. 7. Types of model by publication

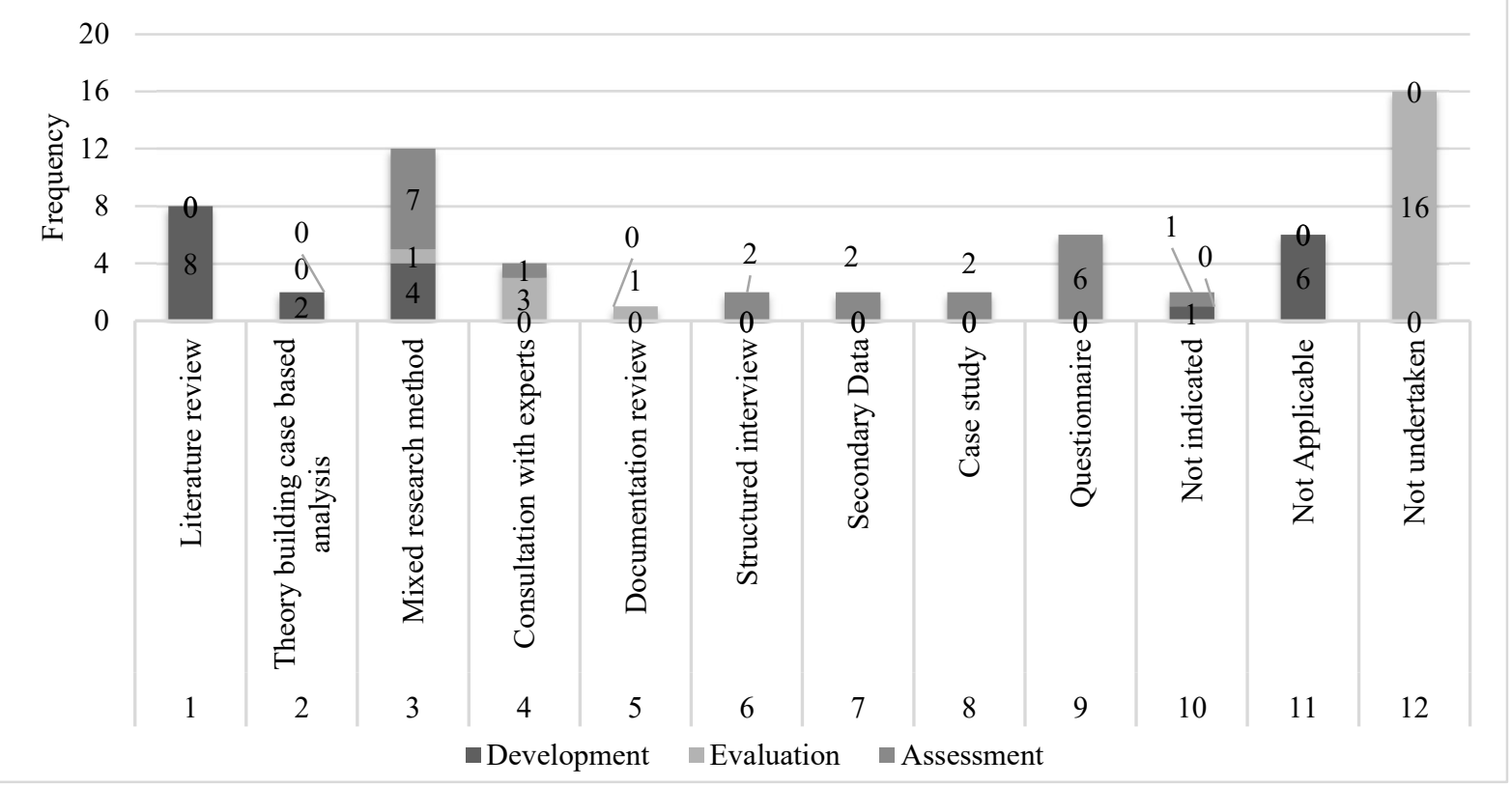

Fig. 8. Methods of model development, evaluation and assessment

\subsection{Policy and Managerial Implications}

According to the findings of this research, the significant challenges of maturity models in the public-private partnership are lack of empirical validation, lack of a roadmap for improvement, lack of an underlying theoretical base resulting in lack of direction, and difficulty in interpreting the results of the model. Furthermore, another challenge is the lack of a rigorous scientific process in developing the models. These challenges have significantly inhibited the potentials of the models to guide improvement and affect the accuracy, reliability, validity, and widespread use of the model in PPPs. Therefore, the study suggests policymakers, regulators, financiers, 
lenders, development finance institutions, and multilateral financial institutions focus on prescriptive models that guide improvements. Such a model should be empirically validated and should utilise rigorous scientific tools such as the Fuzzy Delphi method (FDM) and analytical hierarchy process (AHP) in screening, establishing, and prioritising the variables rather than using literature review only in developing the model. Additionally, a solid theoretical underpinning should be provided to the models to light up the pathways and avoid non-uniformity in the dimensions used that currently affect PPP performance.

\subsection{Limitations and Future Research Directions}

This research has some limitations regarding its sources of literature, its exclusion and inclusion criteria. It is pertinent to indicate that only the following databases, viz: SCOPUS, ScienceDirect, Emerald Insight, EBSCOhost, Google Scholar, and Web of Science, were included in the study. There is a possibility of missing some articles within or outside the selected databases during the searching processes. Also, the tendency of missing some articles due to the search strings used for this study is equally possible. Therefore, the study suggests that future work should broaden the databases and search strings to see if different results can be obtained. Similarly, there is a limitation on the selected articles being used in the domain of PPP. Thus, generalisation of the conclusion to other domains may not be applicable. In the same context, there is a need for uniformity and standardisation in terms/labels and dimensions used in PPP maturity research. Researchers can achieve this uniformity by developing new work based on the previous or theoretical lens. Finally, there is a need for future studies to focus on prescriptive models with emphasis on application and validation if there are to make any positive impact in practice. Additionally, there is also a need for studies to utilise mixed research methods in the development and evaluation, which would significantly enhance models' reliability, accuracy, usefulness, and value in practice.

\section{Acknowledgement}

The authors would like to acknowledge the scholarship provided by Universiti Teknologi PETRONAS to pursue this research.

\section{References}

Al-shareem, K. M, Yusof, N. A., and Roosli, R. (2013). Readiness to Adopt Public-Private Partnership (PPP) in Housing Development in Yemen. International Conference on Business Innovation, Entrepreneurship and Engineering 2013 (ICOBIEE2013), May 2014.

Al-shareem, K. M., Yusof, N., and Kamal, E. M. (2015). External factors influencing the readiness for implementing public-private partnerships among public and private organizations in Yemen. Journal of Science and Technology Policy Management, 6(1), 5675. https://doi.org/10.1108/JSTPM-07-2014-0030

Atkinson, L. Z. and Cipriani, A. (2018). How to carry out a literature search for a systematic review: a practical guide. BJPsych Advances, 24(2), 74-82. https://doi.org/10.1192/bja.2017.3

Babatunde, S. O., Perera, S., and Zhou, L. (2016). Methodology for developing capability maturity levels for PPP stakeholder organisations using critical success factors. Construction Innovation, 16(1), 81-110. https://doi.org/10.1108/CI-06-2015-0035

Becker, J., Knackstedt, R., and Pöppelbuß, J. (2009). Developing Maturity Models for IT Management. Business \& Information Systems Engineering, 1(3), 213-222. https://doi.org/10.1007/s12599-009-0044-5

Becker, S. (2017). Our City, Our Grid: The energy remunicipalisation trend in Germany. In S. Kishimoto and O. Petitjean (Eds.), Reclaiming Public Services: How Cities and Citizens are turning back privatisation. Transnational Institute.

Bititci, U. S., Garengo, P., Ates, A., and Nudurupati, S. S. (2015). Value of maturity models in performance measurement. International Journal of Production Research, 53(10), 3062-3085. https://doi.org/10.1080/00207543.2014.970709

Casady, C. B., Eriksson, K., Levitt, R. E., and Scott, W. R. (2020). (Re)defining public-private partnerships (PPPs) in the new public governance (NPG) paradigm: an institutional maturity perspective. Public Management Review, 22(2), 161-183. https://doi.org/10.1080/14719037.2019.1577909

Casady, C., Eriksson, K., Levitt, R., and Scott, W. R. (2018). Examining the State of Public-Private Partnership (PPP) Institutionalization in the United States. Engineering Project Organization Journal, 8(1). https://doi.org/10.25219/epoj.2018.00109

Chileshe, N. and Kavishe, N. (2020). Readiness assessment of public-private partnerships (PPPs) adoption in developing countries: the case of Tanzania. Built Environment Project and Asset Management, ahead-of-p(ahead-of-print).

https://doi.org/10.1108/BEPAM-12-2019-0133

Concordia. (2016). The Concordia Partnership Index.

Correia, E., Carvalho, H., Azevedo, S., and Govindan, K. (2017). Maturity Models in Supply Chain Sustainability: A Systematic Literature Review. Sustainability, $9(1), \quad 64$. https://doi.org/10.3390/su9010064

de Bruin, T., Freeze, R., Kulkarni, U., and Rosemann, M. (2005). Understanding the main phases of developing a maturity assessment model. ACIS 2005 Proceedings 16th Australasian Conference on Information Systems, 109.

Deloitte. (2007). Closing America's Infrastructure Gap: The Role of Public-Private Partnerships. In Deloitte Research Study.

Filho, A. P. G. and Waterson, P. (2018). Maturity models and safety culture: A critical review. Safety Science, 105 (December 2017), 192-211. https://doi.org/10.1016/j.ssci.2018.02.017

García-Mireles, G. A., Moraga, M. Á., and García, F. (2012). Development of maturity models: a systematic literature review. 16th International Conference on Evaluation \& Assessment in Software Engineering (EASE 2012), 2012(1), 279-283. https://doi.org/10.1049/ic.2012.0036

Hahn, H. A. (2013). The Conundrum of Verification and Validation of Social Science-based Models. Procedia Computer Science, 16, 878-887. https://doi.org/10.1016/j.procs.2013.01.092

Hain, S. (2010). Developing a Situational Maturity Model 
for Collaboration (SiMMCo) - Measuring Organizational Readiness. 5th International Conference on Design Science Research in Information Systems and Technology (DESRIST), May, 1-6.

Hall, D. and Hobbs, C. (2017). Public ownership is back on the agenda in the UK. In S. Kishimoto and O. Petitjean (Eds.), Reclaiming Public Services: How Cities and Citizens are turning back privatisation (pp. 131-142).

HM Treasury. (2018). BUDGET 2018 October 2018 (Issue October).

Humphrey, W. S. (1997). Managing Technical People: Innovation, Teamwork, and the Software Process. In The SEI series in software engineering. Addison Wesley. https://doi.org/978-0201545975

Kavishe, N. and Chileshe, N. (2019). Readiness assessment of public-private partnerships implementation within Tanzanian housing projects: Challenges, strategies and approaches. Association of Researchers in Construction Management, ARCOM 2019 - Proceedings of the 35th Annual Conference, 345-354.

Khoshgoftar, M. and Osman, O. (2009). Comparison of maturity models. 2009 2nd IEEE International Conference on Computer Science and Information Technology, 297-301. https://doi.org/10.1109/ICCSIT.2009.5234402

Kishimoto, S. and Petitjean, O. (2017). Reclaiming Public Services: How Cities and Citizens are turning back privatisation. Transnational Institute.

Lobina, E., Satoko, K., and Olivier, P. (2014). Here to Stay: Water Remunicipalisation As a Global Trend. In Public Services International Research Unit (PSIRU), Multinational Observatory and Transnational Institute (TNI).

Maier, A. M., Moultrie, J., and Clarkson, P. J. (2012). Assessing Organizational Capabilities: Reviewing and Guiding the Development of Maturity Grids. IEEE Transactions on Engineering Management, 59(1), 138-159. https://doi.org/10.1109/TEM.2010.2077289

Malik, S. and Kaur, S. (2020). Multi-dimensional publicprivate partnership readiness index: a sub-national analysis of India. Transforming Government: People, Process and Policy, ahead-of-p(ahead-of-print). https://doi.org/10.1108/TG-06-2020-0107

Miyamoto, K. and Biousse, K. (2014). Official Support for Private Sector Participation in Developing Country Infrastructure (Issue 2014).

Moher, D., Liberati, A., Tetzlaff, J., and Altman, D. G. (2009). Preferred Reporting Items for Systematic Reviews and Meta-Analyses: The PRISMA Statement. Journal of Clinical Epidemiology, 62(10), 1006-1012. https://doi.org/10.1016/j.jclinepi.2009.06.005

Nightingale, A. (2009). A guide to systematic literature reviews. Surgery (Oxford), 27(9), 381-384. https://doi.org/10.1016/j.mpsur.2009.07.005

Office of Government Commerce (OGC). (2010). Portfolio, Programme and Project Management Maturity Model.

Pereira, R. and Serrano, J. (2020). A review of methods used on IT maturity models development: A systematic literature review and a critical analysis. Journal of Information Technology, 35(2), 161-178. https://doi.org/10.1177/0268396219886874

Phungula, M. G. (2008). Review and analysis of organisational project management maturity of the South African government departments involved in Public-Private Partnership (PPP) projects. The University of South Africa.

Proença, D. and Borbinha, J. (2016). Maturity Models for Information Systems - A State of the Art. Procedia Computer Science, 100, 1042-1049. https://doi.org/10.1016/j.procs.2016.09.279

Project Management Institute (PMI). (2013). Organizational project management maturity model (OPM3) Knowledge Foundation. Project Management Institute, Inc.

Putri, R. and Wirahadikusumah, R. D. (2019). Readiness of local government in PPP project development - case of LRT Bandung. In R. D. Wirahadikusumah, B. Hasiholan, and P. Kusumaningrum (Eds.), MATEC Web of Conferences (Vol. 270, p. 05002). https://doi.org/10.1051/matecconf/201927005002

Romero, M. J. (2015). What lies beneath? A critical assessment of PPPs and their impact on sustainable development.

Rozenberg, J. and Fay, M. (2019). Beyond the Gap: How Countries Can Afford the Infrastructure They Need while Protecting the Planet (J. Rozenberg and M. Fay (eds.)). Washington, DC: World Bank. https://doi.org/10.1596/978-1-4648-1363-4

Ruikar, K., Anumba, C. J., and Carrillo, P. M. (2006). VERDICT - An e-readiness assessment application for construction companies. Automation in Construction, $15(1)$ 98-110. https://doi.org/10.1016/j.autcon.2005.02.009

Rwelamila, P. D. and Phungula, M. G. (2009). Managing the complexity of public-private partnerships initiatives: How mature are South African public institutions? In: Dainty, A. (Ed) Proceedings of the 25th Annual Association of Researchers in Construction Management (ARCOM) Conference 2009 -, 7-9 September, 445-454.

Smith, V., Devane, D., Begley, C. M., and Clarke, M. (2011). Methodology in conducting a systematic review of systematic reviews of healthcare interventions. BMC Medical Research Methodology, 11(1), 1-6. https://doi.org/10.1186/1471-2288-11-15

Solli-Sæther, H. and Gottschalk, P. (2010). The Modeling Process for Stage Models. Journal of Organizational Computing and Electronic Commerce, 20(3), 279-293. https://doi.org/10.1080/10919392.2010.494535

Soomro, S. A., Soomro, M. A., and Memon, A. H. (2016). Assessing Country's Readiness for adopting Transportation Public-Private Partnerships: The Case of Pakistan. IOSR Journal of Mechanical and Civil Engineering, 13(04), 66-73. https://doi.org/10.9790/1684-1304056673

Sornette, D., Davis, A. B., Ide, K., Vixie, K. R., Pisarenko, V., and Kamm, J. R. (2007). Algorithm for model validation: Theory and applications. Proceedings of the National Academy of Sciences, 104(16), 6562-6567. https://doi.org/10.1073/pnas.0611677104

Tarhan, A., Turetken, O., and Reijers, H. A. (2016). Business process maturity models: A systematic literature review. Information and Software 
Technology, 75, 122-134. https://doi.org/10.1016/j.infsof.2016.01.010

Tawfik, G. M., Dila, K. A. S., Mohamed, M. Y. F., Tam, D. N. H., Kien, N. D., Ahmed, A. M., and Huy, N. T. (2019). A step by step guide for conducting a systematic review and meta-analysis with simulation data. Tropical Medicine and Health, 47(1), 1-9. https://doi.org/10.1186/s41182-019-0165-6

The Economist Intelligence Unit (EIU). (2015). Evaluating the environment for public-private partnerships in Africa: The 2015 Infrascope.

Umar, A. A., Zawawi, N. A. W. A., and Abdul-Aziz, A.R. (2019). Exploratory factor analysis of skills requirement for PPP contract governance. Built Environment Project and Asset Management, 9(2), 277-290. https://doi.org/10.1108/BEPAM-01-20180011

UNECE. (2018). Guiding Principles on People-First Public-Private Partnerships (PPPs) for the United Nations Sustainable Development Goals (UN SDGs): Part II 1-The 8 Guiding Principles for People-First PPPs in Support of the UN SDGs Note by the Secretariat.

United Nations Economic and Social Commission for Asia and the Pacific (UNESCAP). (2014). Public-private Partnerships Readiness Assessment.

United Nations Economic Commission for Europe (UNECE). (2011). UNECE_National PPP readiness self-assessment_english.

United Nations Economic Commission for Europe (UNECE). (2013). UNECE National PPP Readiness Assessment Report Belarus.

Verhoest, K., Petersen, O. H., Scherrer, W., and Murwantara Soecipto, R. (2014). Policy commitment, legal and regulatory framework, and institutional support for PPP in international comparison: Indexing countries readiness for taking up PPP. In Working Papers in Economics and Finance (Working Papers in Economics and Finance, No. 2014-03; Vols. 2014-03).

Verhoest, K.ss, Petersen, O. H., Scherrer, W., and Soecipto, R. M. (2015). How Do Governments Support the Development of Public-Private Partnerships? Measuring and Comparing PPP Governmental Support in 20 European Countries. Transport Reviews, 35(2), $118-139$.

https://doi.org/10.1080/01441647.2014.993746

Whitfield, D. (2017). PFI / PPP Buyouts, Bailouts, Terminations and Major Problem Contracts in UK. In European Services Strategy Unit Research (Issue 9).

World Bank. (2016). Country Readiness Diagnostic for Public-Private Partnerships. In World Bank (Issue June).

World Bank. (2020). Benchmarking Infrastructure Development 2020: Assessing Regulatory Quality to Prepare, Procure, and Manage PPPs and Traditional Public Investment in Infrastructure Projects.

World Bank. (2021a). Data on Private Participation in Infrastructure https://ppi.worldbank.org/en/ppidata

World Bank. (2021b). Private Participation in Infrastructure (PPI) 2020 Annual Report.

Xiao, Y. and Watson, M. (2019). Guidance on Conducting a Systematic Literature Review. Journal of Planning
Education and Research, 39(1), 93-112. https://doi.org/10.1177/0739456X17723971

Yescombe, E. R. (2017). Public-Private Partnerships in Sub-Saharan Africa Case Studies for Policymakers 2017. In Journal of Chemical Information and Modeling (Vol. 53, Issue 9). Mkuki na Nyota Publishers, UONGOZI Institute.

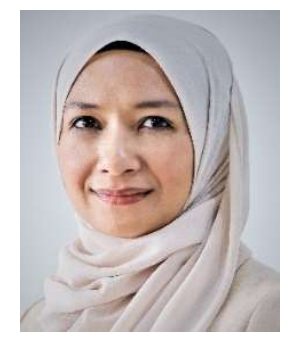

Noor Amila Wan Abdullah Zawawi is an associate professor in the Department of Civil \& Environmental Engineering, Universiti Teknologi PETRONAS (UTP). She is currently the Director of the Institute of Sustainable Building (ISB), UTP. Associate Prof. Amila obtained her Ph.D. degree in Built Environment at International Islamic University Malaysia, a master's degree in Building Technology at the Universiti Sains Malaysia, and a bachelor's degree in Housing, Building \& Planning at the Universiti Sains Malaysia. Her primary areas of interest are Construction Management, Building Technology, Decision Support Systems, Building Information Modelling, and Decommissioning of Offshore Platforms, and she has published over 70 journal and conference publications.

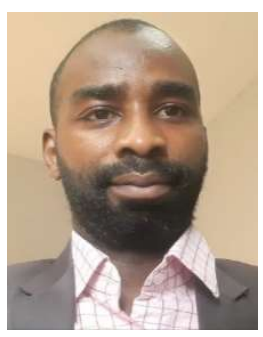

Yusuf Umar Datti is a PhD student in the Department of Civil Engineering, Universiti Teknologi Petronas, Malaysia. Mr. Yusuf holds a master's degree in Quantity Surveying at Heriot-Watt University, Dubai, and a bachelor's degree in Quantity Surveying at Ahmadu Bello University, Zaria. Nigeria. His primary areas of interest are Public-private partnerships, Sustainability, and Whole Life Cycle Costing. He is a Member of the Nigerian Institute of Quantity Surveyors (NIQS) and a Registered Quantity Surveyor (RQS).

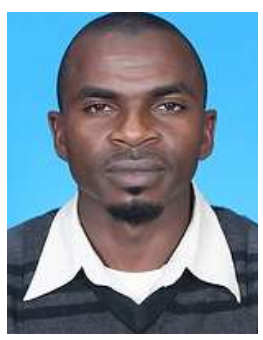

Dr. Abdullahi Ahmed Umar (MRICS, PMP) is a Senior Lecturer in the Department of Civil Engineering and Quantity Surveying at the Military Technological College Muscat. His research interests include Construction project management, Ethics in the construction industry, Public-Private Partnerships (PPP) procurement, and Project finance with particular interests in developing countries.

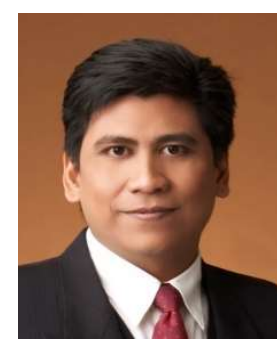

Dr. Muslich Hartadi Sutanto is a Senior Lecturer in the Department of Civil \& Environmental Engineering at Universiti Teknologi PETRONAS (UTP). Dr. Muslich holds a Ph.D. degree in Civil Engineering (Pavement) at the University of Nottingham - UK, a master's degree in Civil Engineering (Transportation Engineering and Management) at ITS - Indonesia and a bachelor's degree in civil engineering at the Universitas Sebelas Maret - Indonesia. His research interests include Pavement Design and Evaluation, Pavement Materials, 
160 Datti, Y. U., Zawawi, N. A. W. A., Umar, A. A., Sutanto, M. H., and Danyaro, K. U.

Preservation Technology and Highway Transportation Systems and Infrastructure.

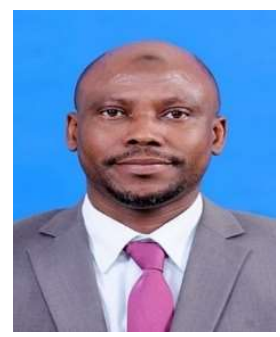

Dr. Kamaluddeen Usman Danyaro is a Lecturer in the Department of Computer and Information Sciences, Universiti Teknologi Petronas. Dr. Kamaluddeen holds a Ph.D. degree in Information Technology at Universiti Teknologi PETRONAS, Malaysia, a master's degree in Business Information Technology at Northumbria University, Newcastle, UK and a bachelor's degree in Mathematics at Bayero University, Kano. His research interests include Data Science, Integration of Oil and Gas Data, and Computational Intelligence. He is a member of the Association for Computing Machinery $(\mathrm{ACM})$ and the Institute of Electrical and Electronics Engineers (IEEE). 
$\checkmark$ Appendix 1. Categorization of PPP maturity models by their main characteristics

\begin{tabular}{|c|c|c|c|c|c|c|c|c|c|}
\hline $\begin{array}{l}\text { Author/Year } \\
\text { of } \\
\text { publication/ } \\
\text { Theoretical } \\
\text { lens }\end{array}$ & $\begin{array}{l}\text { Types of } \\
\text { Publicati } \\
\text { on } \\
\text { (Journal } \\
\text { article, } \\
\text { conferenc } \\
\text { e } \\
\text { proceedin } \\
\text { g article) }\end{array}$ & $\begin{array}{l}\text { Objective of } \\
\text { the Research } \\
\text { (Developmen } \\
\text { t, } \\
\text { Application, } \\
\text { Validation) }\end{array}$ & $\begin{array}{l}\text { Types of } \\
\text { Models } \\
\text { (descriptive } \\
\text { prescriptiv } \\
\text { e, } \\
\text { comparativ } \\
\text { e) }\end{array}$ & $\begin{array}{l}\text { Country of } \\
\text { Origin }\end{array}$ & $\begin{array}{l}\text { Methods } \\
\text { of Model } \\
\text { developm } \\
\text { ent }\end{array}$ & $\begin{array}{l}\text { Methods } \\
\text { of Model } \\
\text { Evaluatio } \\
\text { n }\end{array}$ & $\begin{array}{l}\text { Methods of } \\
\text { Model } \\
\text { Assessment }\end{array}$ & $\begin{array}{l}\text { Maturity/ } \\
\text { Levels }\end{array}$ & Dimensions \\
\hline $\begin{array}{l}\text { World Bank } \\
(2020 b) / \text { No } \\
\text { theoretical } \\
\text { lens }\end{array}$ & Report & $\begin{array}{l}\text { Development, } \\
\text { application } \\
\text { and validation }\end{array}$ & Descriptive & General & $\begin{array}{l}\text { Literature } \\
\text { review }\end{array}$ & $\begin{array}{l}\text { The } \\
\text { Expert } \\
\text { Consultati } \\
\text { ve Group } \\
\text { (ECG) }\end{array}$ & $\begin{array}{l}\text { Questionnai } \\
\text { re survey }\end{array}$ & $0-100 \%$ & $\begin{array}{l}\text { Assesses the quality of Regulatory and } \\
\text { Institutional System for the preparation, } \\
\text { procurement, and contract management } \\
\text { PPPs project } \\
\text { Equal weighted dimensions } \\
\text { - PPP appraisal and prioritisation } \\
\text { (feasibility study) } \\
\text { - Transparency and disclosure } \\
\text { - Standardized PPP contract and } \\
\text { documentation } \\
\text { - PPP monitoring and evaluation } \\
\text { - Qualification and capacity } \\
\text { - Legal and regulatory requirement } \\
\text { - Dispute resolution mechanism }\end{array}$ \\
\hline $\begin{array}{l}\text { Malik and } \\
\text { Kaur } \\
(2020) / \text { No } \\
\text { theoretical } \\
\text { lens }\end{array}$ & $\begin{array}{l}\text { Journal } \\
\text { article }\end{array}$ & $\begin{array}{l}\text { Development } \\
\text { and } \\
\text { application }\end{array}$ & Descriptive & India & $\begin{array}{l}\text { Literature } \\
\text { review }\end{array}$ & & $\begin{array}{l}\text { Secondary } \\
\text { data } \\
\text { Quantitative } \\
\text { research } \\
\text { method }\end{array}$ & $\begin{array}{l}\text { Level } 4 \text { - Leaders } \\
\text { Level } 3 \text { - Performers } \\
\text { Level } 2 \text { - Aspirers } \\
\text { Level } 1 \text { - Laggards }\end{array}$ & $\begin{array}{l}\text { - Previous experience with PPPs } 19 \% \\
\text { - Physical infrastructure } 16 \% \\
\text { - Fiscal constraints } 18 \% \\
\text { - Market conditions } 17 \% \\
\text { - Financial development } 10 \% \\
\text { - Institutional quality and political } \\
\text { stability } 20 \%\end{array}$ \\
\hline $\begin{array}{l}\text { Chileshe and } \\
\text { Kavishe } \\
(2020) / \\
\text { Innovation } \\
\text { diffusion } \\
\text { theory }\end{array}$ & $\begin{array}{l}\text { Journal } \\
\text { article }\end{array}$ & $\begin{array}{l}\text { Development } \\
\text { and } \\
\text { application }\end{array}$ & Descriptive & Tanzania & $\begin{array}{l}\text { Literature } \\
\text { review }\end{array}$ & & $\begin{array}{l}\text { Semi- } \\
\text { structured } \\
\text { interview }\end{array}$ & $\begin{array}{l}\text { 1) Awareness, } \\
\text { 2) Decision to adopt (or } \\
\text { reject) } \\
\text { 3) Initial use }\end{array}$ & $\begin{array}{l}\text { Equal weighted dimensions } \\
\text { - Timing and preparation for adoption of } \\
\text { strategies } \\
\text { - Undertaking of feasibility studies } \\
\text { - Usage of PPP frameworks } \\
\text { - Utilization of experts in the assessment } \\
\text { process } \\
\text { - Capacity building } \\
\text { - Evaluation and selection of private } \\
\text { partners }\end{array}$ \\
\hline $\begin{array}{l}\text { Casady et al. } \\
(2020) / \text { Instit } \\
\text { utional } \\
\text { theory }\end{array}$ & $\begin{array}{l}\text { Journal } \\
\text { article }\end{array}$ & $\begin{array}{l}\text { Development } \\
\text { and } \\
\text { application }\end{array}$ & Descriptive & USA & $\begin{array}{l}\text { Theory } \\
\text { building } \\
\text { case-based } \\
\text { analysis }\end{array}$ & & $\begin{array}{l}\text { Case } \\
\text { analysis and } \\
\text { literature } \\
\text { review }\end{array}$ & & $\begin{array}{l}\text { Equal weighted dimensions } \\
\text { - Proliferation of legal frameworks } \\
\text { - Growing government support and } \\
\text { utilization of PPPs } \\
\text { - Utilization of PPP- enabling } \\
\text { organizations }\end{array}$ \\
\hline
\end{tabular}




\begin{tabular}{|c|c|c|c|c|c|c|c|c|c|}
\hline $\begin{array}{l}\text { Kavishe and } \\
\text { Chileshe } \\
(2019) / \\
\text { Innovation } \\
\text { diffusion } \\
\text { theory }\end{array}$ & $\begin{array}{l}\text { Conferenc } \\
\text { e } \\
\text { Proceedin } \\
\text { gs }\end{array}$ & $\begin{array}{l}\text { Development } \\
\text { and } \\
\text { application }\end{array}$ & Descriptive & Tanzania & $\begin{array}{l}\text { Literature } \\
\text { review }\end{array}$ & & $\begin{array}{l}\text { Semi- } \\
\text { structured } \\
\text { interview }\end{array}$ & $\begin{array}{l}\text { 1) Awareness, } \\
\text { 2) Decision to adopt (or } \\
\text { reject) } \\
\text { 3) Initial use } \\
\text { 4) Continued use }\end{array}$ & $\begin{array}{l}\text { Equal weighted dimensions } \\
\text { - Timing and preparation for adoption of } \\
\text { strategies } \\
\text { - Undertaking of feasibility studies } \\
\text { - Usage of PPP frameworks } \\
\text { - Utilization of experts in the assessment } \\
\text { process } \\
\text { - Capacity building } \\
\text { - Evaluation and selection of private } \\
\text { partners }\end{array}$ \\
\hline $\begin{array}{l}\text { Putri and } \\
\text { Wirahadikus } \\
\text { umah } \\
(2019) / \text { No } \\
\text { theoretical } \\
\text { lens }\end{array}$ & $\begin{array}{l}\text { Conferenc } \\
\text { e } \\
\text { Proceedin } \\
\text { g }\end{array}$ & $\begin{array}{l}\text { Development, } \\
\text { application } \\
\text { and validation }\end{array}$ & Descriptive & Indonesia & $\begin{array}{l}\text { Literature } \\
\text { review and } \\
\text { preliminar } \\
\text { y analysis }\end{array}$ & $\begin{array}{l}\text { Expert } \\
\text { opinion } \\
\text { (Question } \\
\text { naire and } \\
\text { structured } \\
\text { interview) }\end{array}$ & $\begin{array}{l}\text { Case study - } \\
\text { (Interviews - } \\
\text { Five-point } \\
\text { likert scale) }\end{array}$ & $\begin{array}{l}\text { 1) Not ready to implement } \\
\text { the project with the scheme } \\
\text { PPP, for readiness value } \\
\text { below } 50 . \\
\text { 2) Tend to be ready to carry } \\
\text { out projects under the PPP } \\
\text { scheme, for readiness } \\
\text { values equal to and above } \\
50 .\end{array}$ & $\begin{array}{l}\text { Equal weighted dimensions } \\
\text { - Condition of Government } \\
\text { - Government Policy } \\
\text { - Government's Capacity } \\
\text { - Regulation } \\
\text { - PPP Contract Management } \\
\text { - Sustainable Development } \\
\text { - Project Management } \\
\text { - Project Procurement } \\
\text { - Financial }\end{array}$ \\
\hline $\begin{array}{l}\text { Casady et al. } \\
(2018) / \\
\text { Johnson et } \\
\text { al.'s (2006) } \\
\text { four phases } \\
\text { of } \\
\text { institutionali } \\
\text { sation and } \\
\text { Mrak's } \\
\text { (2014) three } \\
\text { models of } \\
\text { PPP } \\
\text { institutionali } \\
\text { sation }\end{array}$ & $\begin{array}{l}\text { Journal } \\
\text { article }\end{array}$ & $\begin{array}{l}\text { Development } \\
\text { and } \\
\text { application }\end{array}$ & Descriptive & USA & $\begin{array}{l}\text { Theory } \\
\text { building } \\
\text { case-based } \\
\text { analysis }\end{array}$ & & $\begin{array}{l}\text { Case } \\
\text { analysis and } \\
\text { literature } \\
\text { review }\end{array}$ & $\begin{array}{l}\text { Johnson et al.'s (2006) } \\
\text { four phases of } \\
\text { institutionalisation } \\
\text { 1) Innovation, } \\
\text { 2) Local validation, } \\
\text { 3) Diffusion, and } \\
\text { 4) General validation } \\
\text { Mrak's (2014) three } \\
\text { models of PPP } \\
\text { institutionalisation } \\
\text { 1) Centralized, } \\
\text { 2) Decentralized } \\
\text { 3) Mixed }\end{array}$ & $\begin{array}{l}\text { Equal weighted dimensions } \\
\text { - PPP units } \\
\text { - PPP policy } \\
\text { - Transparent project prioritisation } \\
\text { frameworks } \\
\text { - Uniform procurement procedures and } \\
\text { - standardised contracts } \\
\text { - Infrastructure deficit } \\
\text { - Fiscal Constraint } \\
\text { - Legal and regulatory framework } \\
\text { - political stability and commitment }\end{array}$ \\
\hline $\begin{array}{l}\text { Concordia } \\
(2016) / N o \\
\text { theoretical } \\
\text { lens }\end{array}$ & Report & $\begin{array}{l}\text { Development } \\
\text { and } \\
\text { application }\end{array}$ & Descriptive & General & $\begin{array}{l}\text { Literature } \\
\text { review and } \\
\text { expert } \\
\text { panel }\end{array}$ & & $\begin{array}{l}\text { Secondary } \\
\text { data } \\
\text { Quantitative } \\
\text { research } \\
\text { method }\end{array}$ & $0-100 \%$ & $\begin{array}{l}\text { - Political Environment Analysis } 40 \% \\
\text { - Investment Climate Analysis } \quad 30 \% \\
\text { - Infrastructure Deficit Analysis } 30 \%\end{array}$ \\
\hline $\begin{array}{l}\text { Soomro et al. } \\
(2016) / \text { No } \\
\text { theoretical } \\
\text { lens }\end{array}$ & $\begin{array}{l}\text { Journal } \\
\text { article }\end{array}$ & Application & Descriptive & Pakistan & & & $\begin{array}{l}\text { Expert } \\
\text { Group - } \\
\text { Questionnai } \\
\text { re and } \\
\text { structured } \\
\text { interview }\end{array}$ & $0-100 \%$ & $\begin{array}{l}\text { Equal weighted dimensions } \\
\text { - macroeconomic environment } \\
\text { - business climate } \\
\text { - financial environment } \\
\text { - legal and governance environment } \\
\text { - legal and regulatory provision for PPP } \\
\text { - PPP policy framework } \\
\text { - PPP capacity }\end{array}$ \\
\hline
\end{tabular}




\begin{tabular}{|c|c|c|c|c|c|c|c|c|}
\hline $\begin{array}{l}\text { Babatunde et } \\
\text { al. }(2016) / \text { No } \\
\text { theoretical } \\
\text { lens }\end{array}$ & $\begin{array}{l}\text { Journal } \\
\text { article }\end{array}$ & $\begin{array}{l}\text { Development, } \\
\text { application } \\
\text { and validation }\end{array}$ & Prescriptive & Nigeria & $\begin{array}{l}\text { Literature } \\
\text { review }\end{array}$ & $\begin{array}{l}\text { Expert } \\
\text { forum - } \\
\text { Questionn } \\
\text { aire } \\
\text { survey }\end{array}$ & $\begin{array}{l}\text { Case studies } \\
-\quad \text { (semi- } \\
\text { structured } \\
\text { interview) } \\
\text { and } \\
\text { documentar } \\
\text { y review }\end{array}$ & $\begin{array}{lccr}\text { Level } & 1 & - & \text { Ad hoc } \\
\text { Level } & 2 & - & \text { Repeatable } \\
\text { Level } & 3 & - & \text { Defined } \\
\text { Level } & 4 & - & \text { Managed } \\
\text { Level } & 5-\text { Optimising }\end{array}$ \\
\hline
\end{tabular}

- PPP process: project selection and

contracting

- PPP process: post-selection,

- social dimension of PPP policy

Equal weighted dimensions

- Government involvement by providing guarantees

- Political support

- Competitive procurement process

- Transparency in the procurement

process

- Availability of suitable and adequate

financial market

- Project economic viability

- Commitment and responsibility of

public \& private sectors

- Project technical feasibility

- Appropriate risk allocation and risk-

sharing

- Appropriate project identification

- Technical innovation and technology transfer

- Thorough and realistic assessment of the cost and benefits

- Strong and good private consortium

- Favourable legal framework

\section{Questionnai 1)Yes \\ 2) $\mathrm{NO}$}

\section{(2016)/ No}

theoretical

lens

\begin{tabular}{|c|c|c|c|c|c|}
\hline $\begin{array}{l}\text { Al-shareem } \\
\text { et al. } \\
(2015 a) / R e a d \\
\text { iness theory }\end{array}$ & $\begin{array}{l}\text { Journal } \\
\text { article }\end{array}$ & $\begin{array}{l}\text { Development } \\
\text { and } \\
\text { application }\end{array}$ & Descriptive & Yemen & $\begin{array}{l}\text { Literature } \\
\text { review }\end{array}$ \\
\hline $\begin{array}{l}\text { Verhoest et } \\
\text { al. } \\
(2015) / I n s t i t \\
\text { utional } \\
\text { theory }\end{array}$ & $\begin{array}{l}\text { Journal } \\
\text { article }\end{array}$ & $\begin{array}{l}\text { Development } \\
\text { and } \\
\text { application }\end{array}$ & Descriptive & $\begin{array}{l}20 \text { European } \\
\text { countries }\end{array}$ & $\begin{array}{l}\text { Literature } \\
\text { review }\end{array}$ \\
\hline $\begin{array}{l}\text { EIU (2015)/ } \\
\text { No } \\
\text { theoretical }\end{array}$ & Report & $\begin{array}{l}\text { Development } \\
\text { and } \\
\text { application }\end{array}$ & Descriptive & Africa & $\begin{array}{l}\text { Literature } \\
\text { review and } \\
\text { workshop }\end{array}$ \\
\hline
\end{tabular}

\begin{tabular}{llr} 
Questionnai & \multicolumn{1}{l}{ 1) Optimism } \\
re & $\begin{array}{l}\text { 2) Innovativeness } \\
\text { 3) Discomfort }\end{array}$ \\
& 4) Insecurity \\
Document & Score 1 $1-$ & Initialized \\
analysis and & Score 2 - & Emerging \\
interview & Score3- & Developed \\
& \multicolumn{3}{c}{ Score4- Mature } \\
Interviews, & 1) Mature & $80-100$ \\
questionnair & 2) Developed & $60-79.9$ \\
es and & 3) Emerging & $30-59.9$
\end{tabular} 4) Nascent 0-29.9
Equal weighted dimensions

- PPP experience

- Stakeholder support and ownership

- Legislative and regulatory framework

- Institutional framework

- Funding and managing fiscal risk

- Access to finance

- Transparency and disclosure

Equal weighted dimensions

- Market Readiness

- Government policies

- Environmental Uncertainty

Equal weighted dimensions

- Policy and political commitment

- Legal and regulatory framework

- PPP- supporting bodies

- Legal and regulatory framework $25 \%$

- Institutional framework $\quad 20 \%$

- Operational maturity $\quad 15 \%$

- Investment climate 


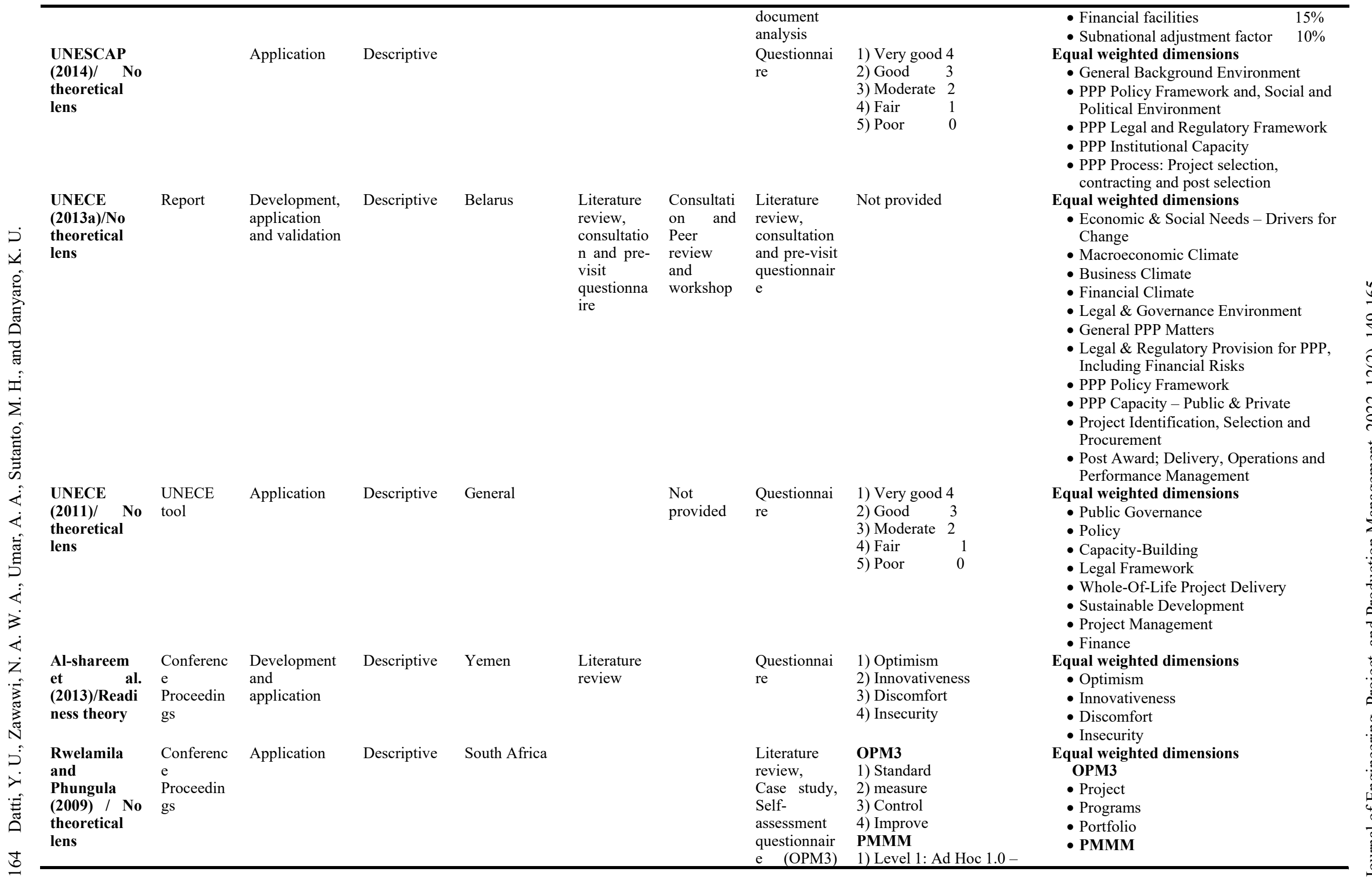




\begin{tabular}{|c|c|c|c|c|c|c|c|c|}
\hline & & & & & & $\begin{array}{l}\text { and Open- } \\
\text { ended } \\
\text { structured } \\
\text { Interview } \\
\text { (PMM) }\end{array}$ & $\begin{array}{l}\text { 1.9 } \\
\text { 2) Level 2: Planned 2.0- } \\
\text { 2.9 } \\
\text { 3) Level 3: Managed 3.0- } \\
\text { 3.9 } \\
\text { 4) Level 4: Integrated } 4.0- \\
\text { 4.9 } \\
\text { 5) Level 5: Sustained } 5.0\end{array}$ & $\begin{array}{l}\text { - Knowledge Management } \\
\text { - Process Standards, Methods and } \\
\text { Procedures } \\
\text { - Technologies } \\
\text { - Decision Support } \\
\text { - Portfolio and Resource Management } \\
\text { - Professional Development } \\
\text { - Continuous Process Improvement }\end{array}$ \\
\hline $\begin{array}{l}\text { Phungula } \\
(2008) / \text { No } \\
\text { theoretical } \\
\text { lens }\end{array}$ & Thesis & Application & Descriptive & South Africa & $\begin{array}{l}\text { Document } \\
\text { ation } \\
\text { review }\end{array}$ & $\begin{array}{l}\text { Literature } \\
\text { review, } \\
\text { Case study, } \\
\text { Self- } \\
\text { assessment } \\
\text { questionnair } \\
\text { e (OPM3) } \\
\text { and Open- } \\
\text { ended } \\
\text { structured } \\
\text { Interview } \\
\text { (PMM) }\end{array}$ & $\begin{array}{l}\text { OPM3 } \\
\text { 1) Standard } \\
\text { 2) measure } \\
\text { 3) Control } \\
\text { 4) Improve } \\
\text { PMMM } \\
\text { 1) Level 1: Ad Hoc } 1.0- \\
\text { 1.9 } \\
\text { 2) Level 2: Planned 2.0- } \\
\text { 2.9 } \\
\text { 3) Level 3: Managed } 3.0- \\
\text { 3.9 } \\
\text { 4) Level 4: Integrated } 4.0- \\
\text { 4.9 } \\
\text { 5) Level 5: Sustained } 5.0\end{array}$ & $\begin{array}{l}\text { Equal weighted dimensions } \\
\text { OPM3 } \\
\text { - } \text { Project } \\
\text { - } \text { Programs } \\
\text { - Portfolio } \\
\text { - } \text { PMMM } \\
\text { - } \text { Prowledge Management Standards, Methods and } \\
\text { - } \text { Procedures } \\
\text { - } \text { Dechnologies } \\
\text { - Portfolio Support } \\
\text { - } \text { Management Resource } \\
\text { - } \text { Professional Development } \\
\text { Continuous Process Improvement }\end{array}$ \\
\hline $\begin{array}{l}\text { Deloitte } \\
(2007 a) / \quad \text { No } \\
\text { theoretical } \\
\text { lens }\end{array}$ & Report & Development & Descriptive & USA & $\begin{array}{l}\text { Not } \\
\text { applicable }\end{array}$ & $\begin{array}{l}\text { Not } \\
\text { applicable }\end{array}$ & $\begin{array}{l}\text { 1) Stage } 1 \\
\text { 2) Stage } 2 \\
\text { 3) Stage } 3\end{array}$ & 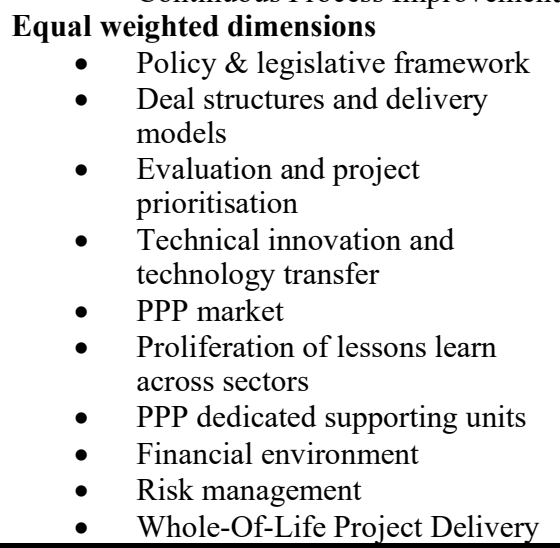 \\
\hline
\end{tabular}

